\title{
ASSESSMENT OF THE STATE OF SOIL-VEGETATION COMPLEXES EXPOSED TO POWDER-GAS EMISSIONS OF NONFERROUS METALLURGY ENTERPRISES
}

\author{
Alexey Strizhenok ${ }^{1}$, Denis Korelskiy' \\ 1 Saint-Petersburg Mining University, 21 $1^{\text {st }}$ Vasilevsky Ostrov, Line 2, Saint Petersburg, 199106, Russia, e-mail: \\ alexeystrizhenok@mail.ru,dnk1984@mail.ru
}

Received: 2016.06.08

Accepted: 2016.08.08

Published: 2016.09.20

\begin{abstract}
Environmental monitoring and state assessment of soil and vegetation in forest ecosystems, exposed to influence of industrial pollution of the nonferrous metallurgy enterprises, was the aim of conducted research. The object of the research was the JSC „Severonikel", where the territory of anthropogenic influence is about 1,5 thousand square kilometers. More than 100 samples of plants and upper soil horizons, which were sampled at various distances from the manufacturing entities of enterprise, including background areas, were the result of the scientific expedition. All samples were analyzed in the laboratory for heavy metals content. It allowed to determine the general degree of contamination of the soil at different distances from the enterprise and to establish the migration patterns and accumulation of heavy metals in different horizons.
\end{abstract}

Keywords: nonferrous metallurgy, environment, pollution, vegetation, soil, heavy metals, reclamation.

\section{INTRODUCTION}

The anthropogenic impact has become one of the most important environmental factors, which are influenced by the environmental-economic state of areas, in recent decades. Intensive industrial and agricultural use of natural resources has caused significant changes in biogeochemical cycles of the most chemical elements. It primarily refers to heavy metals, the accumulation of which in the environment in high concentrations often associated with anthropogenic activity. A significant part of heavy metals, accumulated into soil, is an important biogeochemical barrier and the main stasis area for plants. Therefore, the soil to the greatest extent experiencing the negative impact due to diverse industrial activities of the human, because it has the ability to accumulation of the technogenesis products, primarily this applies to heavy metals [Strizhenok and Korelskiy 2015].

The area of land, contaminated by heavy metals, in the Russian Federation exceeds 100 million hectares, of which about 5 million hectares have extremely dangerous levels of pollution at the end of 2014 [State report 2014]. Technogenic landscapes are formed on the site of the destroyed natural forest and tundra, most of which for many decades keeps the technogenic desert for various reasons. This means a slowdown or complete absence of self-healing processes of soil in the scope of soil ecology, abrupt slowdown of the recovery of vegetation in the scope of geobotany, deterioration in the quality of the environment for humans in the scope of toxicology and health ecology [Galperin et al. 2006].

One of the most significant examples of intensive anthropogenic load on the natural landscape is the metallurgical complex "Severonikel". The metallurgical complex is located on the Kola Peninsula in close proximity to the administrative border of the Russian Federation with Finland. This complex produces nickel and copper by the method of electrolytic dissociation of Feinstein [Overview of the "Severonikel" 2016].

About 52 trillion tons of sulfur dioxide, up to 200 thousand tons of nickel, about 25 thousand 
tons of sulfuric acid, more than 10 thousand tons of hydrogen sulfide, chlorine, phenol and formaldehyde received in the atmospheric air of region during the functioning of considered metallurgical complex. gaseous emissions, which are moved by wind for tens of kilometers, primarily oxides of sulfur (forming a sulfuric acid in conjunction with atmospheric moisture) and particulate emissions of heavy metals have the strongest anthropogenic impact on the landscape [Lukina 2011].

Such intensive anthropogenic impact led to the formation of technogenic sediments of various capacities on an area of over 1500 square kilometers with concentrations of the mobile forms of $\mathrm{Ni}$ and $\mathrm{Cu}$ in the upper soil horizons from tens to thousands of milligrams per kilogram. The destruction and degradation of natural soil-vegetation complexes are observed at a distance of 3035 kilometers from the production facilities of the metallurgical complex. Accumulated pollutants in the surface layer of soils makes them unsuitable for self-recovery of plant communities, and it is a source of groundwater pollution [Isaeva and Sukhareva 2013].

Thus, it becomes clear that without using complex of reclamation measures, aimed at creating optimal conditions for restoration successions in the phytocenoses, full recovery of plant communities in these territories is impossible.

\section{MATERIALS AND METHODS}

The main methods of research were: system analysis of fundamental scientific works of Russian and foreign scientists on this subject; monitoring, landscape-geochemical, bioindicative, experimental and analytical works in the field and laboratory with a using of modern scientific instrument base; methods of mathematical statistics and forecasting the state of natural complexes affected by the anthropogenic load of the metallurgical complex "Severonikel".

Soil samples were taken in accordance with GOST 28168-89 «Sampling of soils» [GOST 28168-89] and GOST 17.4.4.02-84 «Methods of soil sampling and sample preparation for chemical, bacteriological, helminthological analysis» [GOST 17.4.4.02-84].

The whole scientific instrument base for carrying out field surveys and analysis of collected soil samples and vegetation samples in laboratory were given by the laboratory of Environmental monitoring of the Saint-Petersburg Mining University [Scientific instrument base 2016].

The main methods of chemical analysis of soils and vegetation samples were $\mathrm{x}$-ray fluorescence and atomic absorption methods. It allowed to establish their qualitative and quantitative composition, as well as the degree of contamination of soil and vegetation with heavy metals [Fedorec and Medvedeva 2009].

Cluster analysis and methods of cartographic modeling were used for the identification of areas, where are observed the most intense impact of a metallurgical complex on the natural environment. There are observed the maximum inhibition of vegetation and degradation of soil on these territories. The data used for cluster analysis and cartographic modeling has been extracted by the authors during field observations and laboratory experiments.

\section{RESULTS AND DISCUSSION}

Deposition of heavy metals with the atmospheric precipitation in the form of acid rain is the main way of their ingress from atmospheric air into soil and surface water bodies. The effect of acid rain is manifested on terrestrial and aquatic ecosystems in the radius of more than 100 kilometers from major industrial centers and agglomerations, and in a radius of more than 50 kilometers from major metallurgical enterprises. Ecosystems are influenced by the excess ingress of sulfur and other pollutants on the territory with an intensive acid precipitation. This leads to the acceleration of the processes of degradation of soil cover and vegetation, as well as to decrease the ability of ecosystems to heal itself. Ph-value in soil can reach up 2 to 3 near facilities with the intensive $\mathrm{SO}_{2}$ emissions [McGowen and Basta 2001]. The $\mathrm{SO}_{2}$ emissions of the metallurgical complex "Severonikel" in the atmosphere are in the order of 140 thousand tons per year in recent years.

The north-taiga podzolic soils are the predominant for the region in which the research was conducted. As a result of conducted field and laboratory studies by the authors were revealed that the most sensitive to acid contamination are Al-Fe-humus podzolic soils, but the least sensitive are all heavy, gleyey, peat and riparian soil [Kingery et al. 2001].

Environmental monitoring made it possible to 
ascertain that the industrial wasteland (complete degradation of terrestrial ecosystems) is located in a radius of 5-10 kilometers from the border of the territory of the metallurgical enterprise (depending on the prevailing wind). It is the result of the ingress about 20-30 tons of sulfur and more than 60 tons of heavy metals to the soil in this territory from the air annually. Organogenic horizon of the soil is destroyed, mineral soil horizons (podzolic and alluvial-humus) outcrop on the surface, on which is industrial grey pulverescent-sandy layer with a small thickness ( $0.5-2$ centimeters). In this industrial layer is concentrated close to $7 \%$ of nickel. The ravines began to form in this area, which is currently almost completely devoid of vegetation.

Area of ecosystem degradation surrounds the territory of industrial wasteland. It is located at a distance from 5 up to 15 kilometers from the metallurgical complex. Transition between zones is gradual. Deposition of sulphur compounds reaches 3 tons per square kilometer, the ingress of metals up to 5 tons per square kilometer on the territory of ecosystem degradation annually. It leads to the formation of a considerable area of soil chemical pollution. The appearance of such anthropogenically transformed landscapes is a sparse growth of trees, where the age of pine needles is $2-3$ years (it is $6-7$ years in normal conditions). It is conditioned by the intensive accumulation of pollutants in the needles of pine: content of sulfur reaches up to 3000 milligrams per kilogram, nickel up to 160 milligrams per kilogram, and copper up to 200 milligrams per kilogram. Area of the territory of ecosystems degradation is estimated at 250-300 square kilometers. The average concentration of $\mathrm{SO}_{2}$ in the air area reached up to 0.09 milligrams per cubic meters, but content of nickel and copper are in the range of 0.05-0.07 milligrams per cubic meters. The increase of the total amount of mobile forms of $\mathrm{Ni}$ and $\mathrm{Cu}$ in the humus-accumulative horizon more than 200 milligrams per kilogram may damage the root systems of plants. A further increase of the concentration of heavy metals leads to mass extinction first physiologically active roots, and then larger roots of the plants.

The area of taiga ecosystems destruction situated at a distance from 15 to 30 kilometers from metallurgical complex. Deposition of sulphur compounds reaches up to 2000 kilograms per square kilometers, the amount of metals (nickel, copper, manganese, zinc) are in the range of 50 -500 kilograms per square kilometers on this ter- ritory annually. The average concentration of $\mathrm{SO}_{2}$ in the air area reached up to 0.07 milligrams per cubic meters, but content of nickel and copper are up to 0.008 milligrams per cubic meters. Sparse coniferous forests are characterized for this zone. There are soil lichens in a depressed condition in the territory of taiga ecosystems destruction, but herb-dwarf shrub layer is virtually undestroyed.

The initial stage of the ecosystems damage is recorded at a distance of over 30 kilometers from the metallurgical complex and can take up huge areas, where it has a contact with the territories of other enterprises influence.

A lichen-indications made it possible to establish that the frequency of occurrence of different types of epiphytic lichens is reduced with 62 species in the conventionally-background zone (60-70 km from the enterprise) to 13 species in all types of substrates and only to 2 species on the trunks of pine trees on the territory of impact of the metallurgical complex "Severonikel". The projective cover of lichens decreases with $10-16 \%$ in background conditions up to $0 \%$ in the area of the industrial wasteland.

Almost all characteristics of the soil and its appearance are changed under the influence of the deposition of sulphur compounds together with heavy metals [Bolan et al. 2003]. The experimental studies of the authors made it possible to establish the degree of heavy metals solubility dependence on the soil solution $\mathrm{pH}$-value. It allowed to reveal that the solubility of nickel, copper and manganese in strongly acidic environment in 20-40 times higher than in near-neutral environment. It is conditioned by the increasing of amount of free fulvic acid with the increase of the soil solution acidity. Free fulvic acid bind heavy metals by the forming of stable complex compounds, as a result of what heavy metals pass into a soluble state and become available for plants. The cations of nickel and copper replace the cations of calcium, magnesium, potassium, manganese in absorption complex of organogenic horizon. Therefore, the combined effect of acidic sulfur deposition and heavy metals the most dangerous because it has a synergistic influence. Low buffer capacity of podzolic soils is conductive to a high level of mobile forms of heavy metals on the contaminated sites, but high mobility of elements creates the risk of their leaching beyond the upper horizons and entering in the surface waters and groundwater.

The method of field experiment was used to 
determine the critical values of the content of primary pollutants in man-made sediment, the excess of which can lead to irreversible degradation of natural vegetation complexes. A single dispersion of polymetallic dust, emitted by the metallurgical complex "Severonikel", had produced on the snow cover. Some plots with the area about 1 square meter were laid within the experimental area, where the projective cover "Cladina stellaris" ranged from $0 \%$ to $90 \%$. There were the areas, where the concentration of heavy metals had exceeded the limit of existence of the test object (kind of lechinta "Cladina stellaris"), because of the uneven deposit of pollutants in lichen cover. The choice of the test object is grounded by the ubiquitous presence of lichens of this species on uncontaminated (relatively background) areas of the region. The results of chemical analysis of samples of soil and plants allow to calculate the concentration of heavy metals at which the possible existence and recovery of "Cladina stellaris" in contaminated areas.

\section{CONCLUSIONS}

The classification of the area of metallurgical enterprise influence in the clusters according to the degree of anthropogenic load and according to the level of degradation of soils and vegetation are the result of the research. The areas where is still possible the self-recovery of the ecosystems after the cessation of anthropogenic impact, as well as the areas where the process of self-restoration of ecosystems already is impossible, are identified due to the field and laboratory research. There is necessity of the reclamation of disturbed lands on this territory for the restoring of economic and ecological value of disturbed lands.

Fundamental scientific novelty of the study is a map of the distribution of soil and vegetation contamination by heavy metals and sulphur compounds (Figure 1).

The level of soil and vegetation contamination by heavy metals and sulphur compounds was determined by the ratio of total pollution. The ratio of total pollution is calculated as the sum of relations of the pollutant concentrations to their maximum allowable value. For low level of contamination the ratio of total pollution does not exceed 16 , for medium pollution it not exceed 32 , for high pollution it not exceed 128, but on the areas with very high contamination the ratio of

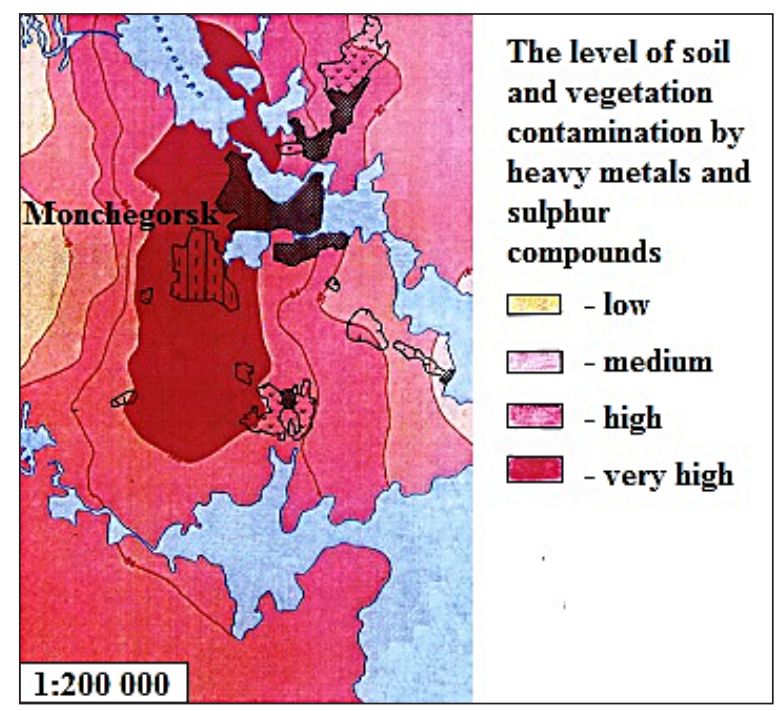

Figure 1. A map of the distribution of soil and vegetation contamination by heavy metals and sulphur compounds

total pollution more than 128 .

This map should be the basis for further studies of anthropogenic impact of the metallurgical complex «Severonikel» in the scope of reducing emissions of heavy metals and sulphur dioxide in atmospheric air, and also in the scope of reclamation of disturbed lands.

\section{REFERENCES}

1. Bolan N., Adriano D., Curtin D. 2003. Soil acidification and liming interactions with nutrient and heavy metal transformation and bioavailability. Advances in Agronomy, 78, 215-272.

2. Fedorec N.G., Medvedeva M.V. 2009. The methodology of soil research of urbanized territories. Petrozavodsk: Karelian Research Centre of Russian Academy, pp. 84.

3. Galperin A.M., Kirichenko Y.V., Shef H.Y. 2006. Anthropogenic arrays and protection of natural resources. Vol. 1., MGGU, pp. 391.

4. GOST 17.4.4.02-84. Methods of soil sampling and sample preparation for chemical, bacteriological, helminthological analysis.

5. GOST 28168-89. Sampling of soils.

6. Isaeva L.G., Sukhareva T.A. 2013. The elemental composition of wild shrubs in the impact zone of "Severonikel": the data of long-term monitoring. Tsvetnye metally, 10, 87-92.

7. Kingery W.L., Simpson A.J., Hayes M.H.B. 2001. Chemical structures of soil organic matter and their interactions with heavy metals. In: H. Magdi Selim and D.L. Sparks (Eds) Heavy metals release in 
soils, 237-245.

8. Lukina Y.M. 2011. Influence of technogenic pollution of the plant "Severonikel" on the growth and development of woody plants. Murmansk state humanities university. Petrozavodsk.

9. McGowen S.L., Basta N.T. 2001. Heavy metal solubility and transport in soil contaminated by mining and smelting. In: H. Magdi Selim and D.L. Sparks (Eds) Heavy metals release in soils, 89-109.

10. Overview of the metallurgical complex „Severonikel". URL: http://www.kolagmk.ru/about/info (02.06.2016).
11. Scientific instrument base of the laboratory of Environmental monitoring of the Saint-Petersburg Mining University. URL: http://spmi.ru/nsciarticle/nsciarticle_13473 (06.06.2016).

12. State report "On condition and protection of the environment of the Russian Federation in 2014". URL: http://www.ecogosdoklad.ru/2014/default. aspx (03.06.2016).

13. Strizhenok A.V., Korelskiy D.S. 2015. Assessment of the anthropogenic impact in the area of tailings storage of the apatite-nepheline ores. Pollution Research, 34(4), 809-811. 